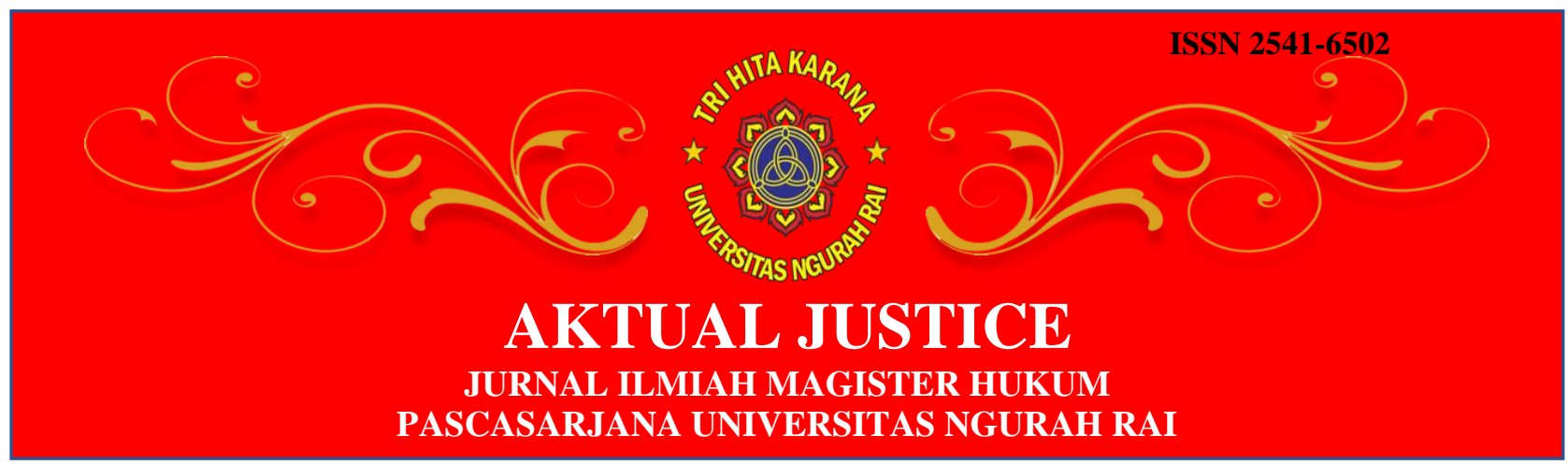

\title{
Politik Hukum Agraria Pada Tanah Ulayat
}

\author{
I Nyoman Prabu Buana Rumiartha
}

Fakultas Hukum Universitas Bali Dwipa, Email : rbp.prabu@gmail.com

\begin{abstract}
The responsive character of Law Number 5 of 1960 concerning Basic Regulations on the Principles of Agrarian Law is reflected in the norms contained in Article 5. The politics of agrarian law on customary land also refers to Article 18B paragraph (2) of the 1945 Constitution which emphasizes: "The state recognizes and respect indigenous peoples and their traditional rights as long as they are still alive and in accordance with the development of society and the principles of the Unitary State of the Republic of Indonesia as regulated in law ". The above constitutional guarantees can then be traced in the UUPA, particularly in Article 5 of the UUPA which states that national agrarian law is based on customary law. This means that the legal strength of land rights for customary communities is highly guaranteed in Indonesia's positive law. That the control of ulayat / customary land is not regulated in writing but it is felt in the mind of each member of the customary law community, besides that the customary law community has historically been founded in philosophy before the birth of the Indonesian State.
\end{abstract}

Keywords: Political Law, Agrarian Affairs, Ulayat Land.

\section{Abstrak}

Karakter responsif Undang-Undang Nomor 5 Tahun 1960 tentang Peraturan Dasar Pokok-Pokok Hukum Agraria tercermin pada norma yang terkandung dalam Pasal 5. Politik hukum agrarian pada tanah adat merujuk pula pada pasal 18B ayat (2) UUD 1945 yang menegaskan: "Negara mengakui dan menghormati kesatuan-kesatuan masyarakat hukum adat beserta hak-hak tradisionalnya sepanjang masih hidup dan sesuai dengan perkembangan masyarakat dan prinsip Negara kesatuan Republik Indonesia yang diatur dalam undang-undang". Jaminan konstitusional di atas kemudian dapat ditelusuri dalam UUPA, khususnya dalam Pasal 5 UUPA yang menyebutkan bahwa hukum agraria nasional didasarkan pada hukum adat. Ini berarti bahwa kekuatan hukum hak-hak atas tanah bagi masyarakat hukum adat sangat dijamin dalam hukum positif Indonesia. Bahwa penguasaan tanah ulayat/tanah adat diatur tidak secara tertulis namun dirasakan ada dalam batin tiap-tiap anggota masyarakat hukum adat, selain itu masyarakat hukum adat secara histori filosofi lebih dulu lahir sebelum Negara Indonesia lahir.

Kata Kunci : Politik Hukum, Agraria, Tanah Ulayat. 


\section{Pendahuluan}

Perihal pengertian politik hukum di Indonesia, terdapat 2 ( dua) aliran pendapat. Pertama, politik hukum dipahami sebagai kebijakan tentang hukum. Kedua, politik hukum dipahami bahwa hukum sebagai produk politik. Pada aliran yang pertama terdapat beberapa pakar hukum yang menganutnya, seperti Padmo Wahyono, ${ }^{1}$ yang memberi batasan tentang politik hukum bahwa: "politik hukum sebagai kebijaksanaan penyelenggara negara tentang apa yang dijadikan kriteria untuk menghukumkan sesuatu. Kebijaksanaan tersebut dapat berkaitan dengan pembentukan hukum, penerapan hukum, lembaga penegak hukum dan penegakannya sendiri ". Singkatnya Padmo menyatakan bahwa "politik hukum sebagai kebijakan dasar yang menentukan arah, bentuk maupun isi hukum yang akan dibentuk".

Demikian pula dengan Teuku Muhammad Radhie ${ }^{2}$ yang menyatakan bahwa: "politik hukum sebagai pernyataan kehendak penguasa negara mengenai hukum yang berlaku di wilayahnya dan mengenai arah ke mana hukum hendak dikembangkan ". Juga Sudarto ${ }^{3}$ yang memberi pengertian bahwa: "politik hukum adalah kebijakan dari negara melalui badan-badan yang berwenang menetapkan peraturanperaturan yang dikehendaki, yang diperkirakan dan digunakan untuk mengekspresikan apa yang terkandung dalam masyarakat dan untuk mencapai apa yang dicita-citakan ".

1 Wahyono, P.(1992). Menyelidik Proses Terbentuknya Perundang-undangan. Jakarta: Forum Keadilan. h. 65.

${ }^{2}$ Martosoewignjo, S.S. (2002). Materi Kuliah Politik Hukum, Bandung: Program Pascasarjana Universitas Padjadjaran. h. 2.

3 Ibid., h. 3. 
Pengertian politik hukum yang dikemukakan Pumadi Purbacaraka \& Soerjono Soekanto ${ }^{4}$ yang memberi defmisi tentang politik hukum, yakni "politik hukum sebagai kegiatan-kegiatan memilih nilai-nilai dan menerapkan nilai-nilai". Mencermati pengertian politikhukum ini, maka terlihat jelas keluasannya. Sebab pengertian ini luas karena menempatkan politik hukum sebagai salah satu bagian dari disiplin hukum. Penganut aliran pikiran politik hukum yang kedua ialah Moh. Mahfud MD, yang mengatakan bahwa berbicara politik hukum berarti kita membicarakan hubungan timbal balik antara politik dengan hukum. Karena itu, tidak dapat disangkal bahwa konfigurasi politik tertentu akan mempengaruhi karakter produk hukum. Tegasnya, Moh. Mahfud MD, merumuskan definisinya sebagai berikut : Politik hukum secara sederhana dapat dirumuskan sebagai kebijaksanaan hukum (legal policy) yang akan atau telah dilaksanakan secara nasional oleh pemerintah; mencakup pula pengertian tentang bagaimana politik mempengaruhi hukum dengan cara melihat konfigurasi kekuatan yang ada di belakang pembuatan dan penegakan hukum itu.

Dalam pandangan Mahfud, hukum tidak dapat hanya dipandang sebagai pasal-pasal yang bersifat imperatif atau keharusan-keharusan yang bersifat das sol/en, melainkan harus dipandang sebagai sub sistem yang dalam kenyataan (dassein) bukan tidak mungkin sangat ditentukan oleh politik, baik dalam perumusan materi dan pasal-pasalnya maupun dalam implementasi dan penegakannya.

Kata "agraria" berasal dari istilah agrarius, ager (Latin) atau agros (Yunani), akker (Belanda) yang artinya tanah pertanian. ${ }^{5}$ lstilah "agraria" ini

4Purbacaraka, P. \& Soekanto, S. (1986). Disiplin Hukum dan Disiplin Sosial. Jakarta: Rajawali. h. 5.

${ }^{5}$ Wargakusumah, H. (2001). Hukum Agraria; Buku Panduan Mahasiswa, Jakarta: Prenhallindo. h. 5. 
dalam Kamus Besar Bahasa Indonesia6 diartikan sebagai: "urusan tanah pertanian atau urusan pemilikan tanah". Sedangkan dalam Black's Law Dictionary disebutkan bahwa "agraria" itu relating to land or to a division or distribution of land; esp, from land or land ownership; Agrarian laws (problems, disputes). Istilah "agraria" sebagai kata benda (noun) berbeda dengan agraria yang digolongkan sebagai kata sifat (adjective) yang dipergunakan untuk membedakan corak kehidupan ( ekonomi) masyarakat pertanian di pedesaan dari masyarakat non-agraris (perdagangan dan industri di perkotaan). Setelah membahas istilah "agraria", maka penulis ingin memapar-kan istilah "hukum agraria". Sebagaimana diketahui bahwa di samping istilah "hukum agraria" (agrarian law) yang telah digunakan oleh para ahli hukum agraria, juga ada istilah "hukum tanah" atau "hukum pertanahan" (land law). Penulis dalam hal ini cenderung sependapat dengan alasan yang menggunakan istilah "hukum agraria", yang menyatakan bahwa hukum agraria tidak hanya mengatur tentang tanah saja, tetapi lingkupnya meliputi seluruh bumi, air dan ruang angkasa termasuk kekayaan alam yang terkandung didalamnya. Sedangkan istilah "hukum tanah" hanya mencakup pengaturan tentang tanah, yakni permukaan bumi. Oleh sebab itu, hukum agraria merupakan genus dari species hukum tanah. Atau dengan lain perkataaan bahwa hukum agraria meliputi pula hukum tanah, atau hukum tanah adalah bagian dari hukum agraria.

Berangkat dari pengertian politik hukum dan hukum agraria di atas, maka dapat memberi kedekatan pemahaman bahwa politik hukum agraria nasional adalah arah kebijakan hukum agraria yang isi dan bentuknya dibuat oleh para penentu kebijakan negara berdasarkan konfigurasi politik yang mempengaruhinya, maka bagaimana politik

6 Tim Penyusun Kamus Pusat Pembinaan dan Pengembangan Bahasa. (1995). Kamus Besar Bahasa Indonesia. Jakarta: Departemen Pendidikan dan Kebudayaan bekerja sama dengan Balai Pustaka. h. 11. 
hukum agraria pada tanah ulayat, yang dalam hal ini pada UUPA ada kaitannya dengan tanah ulayat di Indonesia. Sehubungan dengan hal tersebut di atas maka dirasa perlu penulis mengkaji dan meneliti mengenai Politik Hukum Agraria Pada Tanah Ulayat.

\section{Metode Penelitian}

Agar suatu tulisan yang berdasarkan penelitian dapat dikatakan memenuhi kreteria sebagai karya ilmiah, maka diperlukan suatu metode. Sehubungan hal tersebut, dalam penyusunan tulisan ini, penulis menggunakan metode yuridis normatif yaitu penelitian perundangundangan dan analisa kepustakaan serta bahan-bahan hukum lainya seperti buku-buku dan jurnal-jurnal hukum.

Penelitian ini menggunakan tipe penelitian hukum yuridis normatif yaitu mengkaji dan menganalisa bahan-bahan serta isue-isue hukum berdasarkan peraturan perundang-undangan. Penelitian ini dilakukan untuk memecahkan permasalahan hukum yang timbul sedangkan hasil yang akan di capai adalah preskripsi mengenai apa yang seyogyanya dilakukan.7 Dalam hal ini penelitian Politik Hukum Agraria di Indonesia.

Metode pendekatan yang dipergunakan dalam penelitian ini menggunakan beberapa tekhnik sebagai berikut:

a. Pendekatan Undang-Undang (Statute Aproach)

Pendekatan Undang-Undang yaitu pendekatan dengan menggunakan legislasi dan regulasi. Penelitian hukum dalam level dogmatika hukum tidak dapat melepaskan diri dari pendekatan

${ }^{7}$ Marzuki, P.M. (2005). Penelitian Hukum. Jakarta: Prenada Media. h. 7. 
perundang-undangan karena pokok bahasan yang di telaah berasal dari peraturan perundang-undangan. Pendekatan undang- undang dilakukan dengan menelaah semua undang-undang dan regulasi yang bersangkut paut dengan Politik Hukum Agraria di Indonesia. Untuk mempelajari adakah konsistensi dan kesesuaian antara suatu undang-undang dengan undang-undang lain, atau antara undangundang dengan undang-undang dasar atau antara regulasi dengan undang-undang.

b. Pendekatan konseptual (Conseptual Aproach) yaitu:

Pendekatan yang beranjak dari pandangan-pandangan dan doktrindoktrin yang berkembang di dalam ilmu hukum, agar menemukan ide-ide yang melahirkan pengertian-pengertian hukum, dan asasasas hukum atau argumentasi hukum yang merupakan sandaran peneliti untuk membangun argumentasi hukum dalam memecahkan isu yang dihadapi. ${ }^{8}$ Pendekatan konseptual ini digunakan untuk menemukan pandangan-pandangan dan doktrindoktrin yang berkembang dalam ilmu hukum, kajian prinsipprinsip hukum berkaitan dengan Politik Hukum Agraria di Indonesia.

\section{Hasil Dan Pembahasan}

Politik hukum Agraria adalah sebagaimana yang diamanatkan dalam Pasal 33 ayat (3) UUD 1945 yang kemudian diokomodir Pasal 2 ayat (1) UUPA bahwa, bumi, air dan ruang angkasa termasuk kekayaan alam yang terkandung didalarnnya harus dipergunakan untuk kesejahteraan rakyat. Hasil yang akan dicapai dalam mempelajari politik hukum adalah

\footnotetext{
8 Ibid, h .95.
} 
apakah suatu aturan hukum yang hendak dibuat atau telah dibuat akan mengarah kepada terciptanya suatu :

(1). unifikasi hukum - kodifikasi hukum, ataukah

(2). pluralisme atau pluralisasi hukum (dualisme hukum), ataukah

(3). simpli:fikasi (penyederhanaan) hukum, atau

(4). penyelarasan hukum. ${ }^{9}$

Sasaran kebijakan hukum atau politik hukum (legal policy) ini, yang kemudian dalam tulisan ini menurut hemat penulis akan mengkaji tentang bagaimana arah politik hukum agraria nasional berkenaan dengan perlindungan atau pengakuan atas hukum adat (khususnya hak ulayat masyarakat hukum adat) di era reformasi.

Berbicara politik hukum tentang hak ulayat secara khusus, sama sekali tidak dapat dilepaskan dengan politik hukum agraria secara umum. Kemana arah kebijakan hukum agraria nasional dibuat, juga secara otomatis melekat hak ulayat. Bilamana politik hukum agraria nasional itu responsif, maka dengan sendirinya kebijakan hukum terhadap hak ulayat akan responsif pula. Moh. Mahfud MD, menegaskan UUPA juga memberikan tempat yang proporsional bagi hukum adat, seperti yang tersebut dalam Pasal 5 bahwa hukum agraria yang berlaku atas bumi, air dan ruang angkasa adalah hukum adat yang sudah disaneer dan tidak bertendensi menantang asas unifikasi. Ini menandakan UUP A berkarakter responsif. sebab hukum yang memiliki hukum adat dapat dilihat sebagai hukum yang responsif. Marryman menyebut tradisi hukum adat menganut strategi pembangunan hukum yang responsif. ${ }^{10}$

${ }^{9}$ Wignjosoebroto, S. (1995). Dari Hukum Kolonial Ke Hukum Nasional; Suatu Kajian Tentang Dinamika Sosial - Politik Dalam Perkembangan Hukum Selama Satu Setengah Abad di Indonesia (1840- 1990). Jakarta: Raja Grafindo Persada. h. 9 - 11.

10 Mahfud MD, M. (1998). Politik Hukum Di Indonesia, Jakarta: Pustaka LP3ES Indonesia. h. 347. 
Dalam konteks kesejarahan sesungguhnya kita amat beruntung, karena perancang Undang-Undang Dasar 1945 Prof. Soepomo adalah seorang pakar hukum adat, yang benar-benar mengetahui posisi masyarakat adat di Indonesia dan sehubungan dengan itu mencantumkan pengakuan Negara terhadap masyarakat hukum adat dalam rancangan konstitusi yang sedang di susunnya. Tetapi di sayangkan ,bahwa pengakuan tersebut tidak tercantum secara lugas dalam dicktum UndangUndang Dasar 1945, tetapi hanya dalam penjelasan Pasal 18.

Namun walaupun hanya tercantum dalam penjelasan Pasal 18 UUD 1945 sikap para Founding Fathers tersebut merupakan pendapat original yang harus dirujuk dalam melakukan tafsiran historis terhadap norma hukum yang terkait dengan eksistensi dan hak-hak tradisional masyarakat hukum adat. Sampai sekitar tahun 1960 pengakuan konstitusional terhadap masyarakat hukum adat dan hak-haknya tidak banyak dipersoalkan.

Faktor penyebabnya adalah karena jaminan tersebut sudah dianggap seyogianya demikian, sebagian lagi oleh karena Republik Indonesia masih sibuk dalam mempertahankan kemerdekaan. Namun perlindungan terhadap eksistensi dan hak-hak masyarakat hukum adat merosot tajam sejak tahun 1960, seiiring dengan meningkatnya kepentingan negara terhadap sumber daya alam, yang terdapat dalam wilayah hak ulayat masyarakat hukum ad at, terutama di luar pulau Jawa. Dengan berbagai peraturan perundang-undangan, Negara mengambil berbagai kebijakan yang intinya adalah mengurangi, membatasi hak-hak tradisional serta hak masyarakat hukum adat yang ada, tanpa memberikan ganti rugi sama sekali.

Secara khusus perlu kita catat sikap ambivalen (mendua bertentangan) yang dianut oleh Undang-Undang Pokok Agraria Nomor 5 Tahun 1960 Tentang Pokok-pokok Agraria terhadap hukum adat dan masyarakat hukum adat. Pada suatu sisi Undang-undang ini secara tegas 
menyatakan bahwa hukum adat merupakan sumber dari Hukum Agraria Nasional kita. Namun pada sisi lain eksistensi masyarakat hukum adat dan hak-haknya dibebani beberapa kondisionalitas yang cepat atau lambat membuka peluang untuk dimarginalkannya masyarakan hukum adat tersebut berdasarkan kepentingan umum dan atau kepentingan Negara.

Jadi, karakter responsif Undang-Undang Nomor 5 Tahun 1960 tentang Peraturan Dasar Pokok-Pokok Hukum Agraria tercermin pada norma yang terkandung dalam Pasal 5 bahwa hukum agraria yang berlaku atas bumi, air dan ruang angkasa ialah hukum adat, sepanjang tidak bertentangan dengan kepentingan nasional dan negara, yang berdasarkan atas persatuan bangsa, dengan sosialisme Indonesia serta dengan peraturan-peraturan yang tercantum dalam undang-undang ini dan dengan peraturan perundangan lainnya, segala sesuatu dengan mengindahkan unsur-unsur yang bersandar pada hukum agama.

Norma perlindungan hak ulayat masyarakat hukum adat dalam peraturan perundang-undangan keagrariaan di Indonesia merupakan indikasi responsifnya hukum agraria nasional. Sebab jaminan perlindungan hak-hak masyarakat hukum adat atas tanah merupakan syarat mutlak peraturan perundang-undangan keagrariaan nasional, hal ini merupakan amanat konstitusi sebagaimana yang diatur dalam hukum positif Indonesia mengenai hak-hak masyarakat adat dapat dirujuk pada Pasal 18B ayat (2) UUD 1945 yang menegaskan: "Negara mengakui dan menghormati kesatuan-kesatuan masyarakat hukum adat beserta hak-hak tradisionalnya sepanjang masih hidup dan sesuai dengan perkembangan masyarakat dan prinsip Negara kesatuan Republik Indonesia yang diatur dalam undang-undang". Kemudian dalam Pasal 281 ayat (3) UUD 1945 ditegaskan bahwa: "ldentitas budaya dan hak masyarakat tradisional dihormati selaras dengan perkembangan zaman dan peradaban ". 
Jaminan konstitusional di atas kemudian dapat ditelusuri dalam UUPA, khususnya dalam Pasal 5 UUP A yang menyebutkan bahwa hukum agraria nasional didasarkan pada hukum adat. Ini berarti bahwa kekuatan hukum hak-hak atas tanah bagi masyarakat hukum adat sangat dijamin dalam hukum positif Indonesia. ${ }^{11}$

Keberadaan hak ulayat itu perlu dipastikan mengingat pengertian masyarakat hukum adat masih terdapat penafsiran yang berbeda, sehingga sering terjadi "marginalisasi" masyarakat adat. Melihat kenyataan ini, maka beberapa aliansi masyarakat hukum adat menuntut hak agar mereka diakui keberadaannya dan juga hak-hak masyarakat adatnya. Hak-hak masyarakat adat ini merupakan hak dasar manusia pada umumnya di dunia. Berlakunya universal, karena itu dalam membicarakan perlindungan hak-hak penduduk lokal dapat ditarik dari teori "menentukan nasib sendiri" dalam kerangka Negara kesatuan.12

Tentang eksistensi hak ulayat itu sendiri terdapat 2 ( dua) pandangan sikap, di satu pihak terdapat kekhawatiran bahwa hak ulayat itu semula tidak ada, kemudian dihidupkan lagi. Di pihak lain ada juga kekhawatiran bahwa dengan semakin meningkatnya kebutuhan akan tanah akan semakin mendesak hak ulayat. ${ }^{13}$ Terlebih lagi dengan dimunculkannya berbagai persyaratan akan eksistensi dan implementasi hak ulayat (beschikldngsrecht) masyarakat adat. Pertama, mengenai eksistensinya, apabila menurut kenyataan masih ada. Di daerah mana hak itu tidak ada lagi atau memang tidak pemah ada, tidak akan dihidupkan lagi bahkan tidak akan dilahirkan hak ulayat yang baru. Kedua, mengenai

11 Hutagalung, A.S. (2005). Tebaran Pemikiran Seputar Masalah Hukum Tanah,Lembaga Pemberdayaan Hukum Indonesia". Jakarta: LPID. h. 120.

12 Anaya, S.J. (1994). Indegenous Peoples International Law. New York: Oxford University Press. h. 89.

13 Sumardjono, M.S.W. (2001). Kebijakan Pertanahan; Antara Regulasi dan Implementasi. Jakarta: Penerbit Buku Kompas. h. 54. 
pelaksanaan hak ulayat harus sedemikian rupa, sehingga (1). sesuai dengan kepentingan nasional dan negara berdasarkan atas persatuan bangsa, serta (2). tidak boleh bertentangan dengan undang-undang dan peraturanperaturan yang lebih tinggi.

Pengakuan dengan syarat terhadap hak ulayat tersebut mencerminkan pengaturan secara sistimatis mengenai pengidentifikasian dan penggunaan hak ulayat atas tanah di Indonesia. Sehingga memunculkan kritik yang mendasar: Pertama, bel urn jelasnya indikasi pemahaman ten tang hak ulayat yang hilang atau yang sudah tidak ada, sehingga pada implementasinya akan dapat disalahgunakan oleh pihak penguasa untuk menghilangkan hak ulayat. Kedua, masih begitu dominannya negara atau pemerintah dengan "topeng" kepentingan umum terhadap tanah, sehingga terkadang mengintervensi ruang hidup (labensraum, livingspace) komunitas masyarakat pemilik hak ulayat. Apakah dengan alasan kepentingan umum dapat menghapus norma-norma adat yang berkenaan dengan hak ulayat. Ketiga, argumentasi bertentangan dengan peraturan perundangundangan yang berlaku berarti telah menafikan eksistensi hukum adat itu sendiri. Padahal Undang-Undang Nomor 5 Tahun 1960 mendeklarasikan dirinya bahwa hukum agraria yang berlaku atas bumi, air dan ruang angkasa ialah hukum adat.

Konflik mengenai tanah ulayat sering teijadi dibeberapa daerah Indonesia, misalnya di Aceh, Sumatera Utara, Sumatera Barat, Riau, Kalimantan Barat, Kalimantan Tengah, Kalimantan Timur, Maluku, Ambon, dan Wamena- Papua. ${ }^{14}$ Perlawanan masyarakat hukum adat juga teijadi di Sumatera Selatan, Riau, Bulu Kumba (Sulawesi), dan Wamena. Konflik agraria merata di Indonesia, konflik dan sengketa lahan yang dibiarkan dapat berujung pada konflik sosial, sehingga seharusnya

14 Sarjono, A.P. (2000). Konflik Sosial di Kalimantan Timur. Hutan Indonesia. Edisi 07 Maret,h. 14. 
pemerintah harus mengambil peran di dalam penyelesaian masalah tersebut khususnya Badan Pertanahan Nasional yang mempunyai otoritas untuk itu.

Untuk mengetahui apakah hak ulayat (beschikkingsrecht) itu masih ada, terdapat kriteria yang dapat digunakan sebagai parameter. Adapun kriteria untuk menentukan masih ada atau tidaknya hak ulayat menurut Maria S.W.Sumardjono, ${ }^{15}$ harus dilihat pada 3 (tiga) hal, yakni:

1. Adanya masyarakat hukum adat yang memenuhi ciri-ciri tertentu, sebagi subyek hak ulayat;

2. Adanya tanah/wilayah dengan batas-batas tertentu sebagai labensraum yang merupakan obyek hak ulayat; dan

3. Adanya kewenangan masyarakat hukum adat untuk melakukan tindakan-tindakan tertentu sebagaimana diuraikan di atas.

Dipenuhinya ketiga persyaratan tersebut secara kumulatif, kiranya cukup obyektif sebagai kriteria penentu masih ada atau tidaknya hak ulayat, sehingga misalnya, walaupun ada masyarakat hukum dan ada tanah atau wilayahnya, namun apabila masyarakat hukum tersebut sudah tidak mempunyai kewenangan untuk melakukan tiga tindakan tersebut, maka hak ulayat dapat dikatakan sudah tidak ada lagi. ${ }^{16}$ Justru itu, tanahtanah ulayat seperti "tanah bengkok"dan "tanah titisara" ataupun "tanah hak kaula" ( di Aceh) yang lembaga desanya telah dihapuskan dan menjadi kelurahan, menjadi milik atau diserahkan kepemilikannya kepada pemerintah kabupaten atau kota. Sebab masyarakat hukum adat sudah tidak mempunyai kewenangan atas tanah-tanah ulayat tersebut. ${ }^{17}$

Perihal hak ulayat (beschikkingsrecht) secara yuridis (ius constitutum) telah diatur dalam Pasal 3 Undang-Undang Nomor 5 Tahun 1960 yang

15 Sumardjono, M.S.W. Op.Cit. h. 57.

16 Ibid., h. 57.

17 Ibid. 
menegaskan bahwa Dengan mengingat ketentuan-ketentuan dalam Pasal 1 dan 2 pelaksanaan hak ulayat dan hak-hak yang serupa itu dari masyarakat-masyarakat hukum adat, sepanjang menurut ke- nyataannya masih ada, harus sedemikian rupa sehingga sesuai dengan kepentingan nasional dan negara, yang berdasarkan atas persatuan bangsa serta tidak boleh bertentangan dengan undang-undang dan peraturan-peraturan lain yang lebih tinggi.

Norma yang terkandung dalam Pasal 3 Undang-Undang Nomor 5 Tahun 1960 tersebut, kemudian lebih dijelaskan bahwa:18Ketentuan ini pertama-tama berpangkal pada pengakuan adanya hak ulayat itu di dalam hukum agraria yang baru. Sebagaimana diketahui biarpun menurut kenyataannya hak ulayat itu ada dan berlaku serta diperhatikan pula di dalam keputusan-keputusan hakim, belum pernah hak tersebut diakui secara resmi di dalam undang-undang, dengan akibat bahwa di dalam melaksanakan peraturan-peraturan agrarian hak ulayat itu pada zaman penjajahan dulu sering kali diabaikan. Berhubung dengan disebutnya hak ulayat di dalam UUPA yang pada hakekatnya berarti pula pengakuan hak itu, maka pada dasarnya hak ulayat itu akan diperhatikan, sepanjang hak tersebut menurut kenyataannya memang masih ada pada masyarakat hukum yang bersangkutan.

\section{Kesimpulan}

Politik hukum Agraria adalah sebagaimana yang diamanatkan dalam Pasal 33 ayat (3) UUD 1945 yang kemudian diokomodir Pasal 2 ayat (1) UUPA bahwa, bumi, air dan ruang angkasa termasuk kekayaan alam yang terkandung didalarnnya harus dipergunakan untuk kesejahteraan rakyat. Jaminan konstitusional di atas kemudian dapat ditelusuri dalam

18 Ginting, D. (2009). Kepastian Hukum Hak Atas Tanah Bagi Penanaman Modal Bidang Agrrobisnis di Indonesia. Bandung: Unpad Press. h. 93. 
UUPA, khususnya dalam Pasal 5 UUP A yang menyebutkan bahwa hukum agraria nasional didasarkan pada hukum adat. Ini berarti bahwa kekuatan hukum hak-hak atas tanah bagi masyarakat hukum adat sangat dijamin dalam hukum positif Indonesia. Karakter responsif Undang-Undang Nomor 5 Tahun 1960 tentang Peraturan Dasar Pokok-Pokok Hukum Agraria tercermin pada norma yang terkandung dalam Pasal 5 bahwa hukum agraria yang berlaku atas bumi, air dan ruang angkasa ialah hukum adat, sepanjang tidak bertentangan dengan kepentingan nasional dan negara, yang berdasarkan atas persatuan bangsa, dengan sosialisme Indonesia serta dengan peraturan-peraturan yang tercantum dalam undang-undang ini dan dengan peraturan perundangan lainnya, segala sesuatu dengan mengindahkan unsur-unsur yang bersandar pada hukum agama. Politik hukum agrarian pada tanah adat merujuk pula pada pasal 18B ayat (2) UUD 1945 yang menegaskan: "Negara mengakui dan menghormati kesatuan-kesatuan masyarakat hukum adat beserta hak-hak tradisionalnya sepanjang masih hidup dan sesuai dengan perkembangan masyarakat dan prinsip Negara kesatuan Republik Indonesia yang diatur dalam undang-undang". Kemudian dalam Pasal 281 ayat (3) UUD 1945 ditegaskan bahwa: "ldentitas budaya dan hak masyarakat tradisional dihormati selaras dengan perkembangan zaman dan peradaban ". Jaminan konstitusional di atas kemudian dapat ditelusuri dalam UUPA, khususnya dalam Pasal 5 UUP A yang menyebutkan bahwa hukum agraria nasional didasarkan pada hukum adat. Ini berarti bahwa kekuatan hukum hak-hak atas tanah bagi masyarakat hukum adat sangat dijamin dalam hukum positif Indonesia.

\section{DAFTAR PUSTAKA}

Anaya, S.J. (1994). Indegenous Peoples International Law. New York: Oxford University Press. 
Ginting, D. (2009). Kepastian Hukum Hak Atas Tanah Bagi Penanaman Modal Bidang Agrrobisnis di Indonesia. Bandung: Unpad Press

Hutagalung, A.S. (2005). Tebaran Pemikiran Seputar Masalah Hukum Tanah,Lembaga Pemberdayaan Hukum Indonesia". Jakarta: LPID.

Mahfud MD, M. (1998). Politik Hukum Di Indonesia, Jakarta: Pustaka LP3ES Indonesia.

Martosoewignjo, S.S. (2002). Materi Kuliah Politik Hukum, Bandung: Program Pascasarjana Universitas Padjadjaran.

Marzuki, P.M. (2005). Penelitian Hukum. Jakarta: Prenada Media.

Purbacaraka, P. \& Soekanto, S. (1986). Disiplin Hukum dan Disiplin Sosial. Jakarta: Rajawali.

Sarjono, A.P. (2000). Konflik Sosial di Kalimantan Timur. Hutan Indonesia. Edisi 07 Maret

Sumardjono, M.S.W. (2001). Kebijakan Pertanahan; Antara Regulasi dan Implementasi. Jakarta: Penerbit Buku Kompas.

Tim Penyusun Kamus Pusat Pembinaan dan Pengembangan Bahasa. (1995). Kamus Besar Bahasa Indonesia. Jakarta: Departemen Pendidikan dan Kebudayaan bekerja sama dengan Balai Pustaka.

Wahyono, P.(1992). Menyelidik Proses Terbentuknya Perundang-undangan. Jakarta: Forum Keadilan.

Wargakusumah, H. (2001). Hukum Agraria; Buku Panduan Mahasiswa, Jakarta: Prenhallindo.

Wignjosoebroto, S. (1995). Dari Hukum Kolonial Ke Hukum Nasional; Suatu Kajian Tentang Dinamika Sosial - Politik Dalam Perkembangan Hukum Selama Satu Setengah Abad di Indonesia ( 1840- 1990). Jakarta: Raja Grafindo Persada. 